\title{
Breves comentários sobre algumas obras publicadas em 2018
}

\section{BONILLA, Nora Garita (org.) América Latina y sus pueblos en movimiento.} Heredia/Costa Rica: Letra Maya, 2018.

Esta coletânea reúne dez artigos que tratam de questões relativas ao protagonismo de setores não-hegemônicos na América Latina. Os artigos são assinados por investigadores de diferentes países, oito deles resultantes da experiência que seus autores tiveram no âmbito de um programa colaborativo de investigação em nível de pós-doutorado, em que coube destacado papel à ALAS-Associação Latinoamericana de Sociologia; e dois artigos de autoria de investigadores que participaram da equipe docente do referido programa. Em termos concretos, os artigos abordam temas como: territórios e identidades dos povos centroamericanos, os discursos da imprensa sobre governos democrático-populares, os povos indígenas e a hidrelétrica de Belo Monte, e o extrativismo mineiro no México, entre outros. Também o novo ciclo político na América Latina recebeu atenção. A conferir.

MACEDO, Rogério F.; NOVAES, Henrique T.; LIMA Fo., Paulo A. de (org.) Movimentos sociais e crises contemporâneas (vol. 3). Marília: Lutas Anticapital, 2018.

Esta é a terceira coletânea sobre "movimentos sociais e crises contemporâneas" organizada por um atuante coletivo de estudiosos e militantes das causas populares. O livro, precedido de um prefácio e da apresentação, contém 14 artigos de renomados pesquisadores (do Brasil e de outros países da América Latina), distribuídos em três partes: a primeira é "Revolução Russa, particularidade brasileira e crises contemporâneas"; a segunda, "Movimentos Sociais e governos de esquerda no século XXI"; e a terceira, "Educação, Ciência e Tecnologia na Era da Barbárie". Se bem sejam todos artigos de relevância para quem se preocupa com o que se passa no Brasil e no mundo, a atenção dos/as leitores/as da RBDR talvez convirja, pela temática, para o interessante ensaio "Território, dependência e luta de classes no Brasil", assinado por Evaldo Gomes Junior, Fernando Cézar de Macedo e Pietro Caldeirini Aruto.

OLIVEIRA, Francisco de. Brasil: uma biografia não autorizada. São Paulo: Boitempo, 2018.

O último livro de Francisco de Oliveira, um dos mais importantes intelectuais brasileiros vivos, professor aposentado da USP e pesquisador do Cebrap e Cenedic, reúne dois artigos mais longos, que apareceram em coletâneas nos anos de 2005 e 2006, e quatro textos mais breves, publicados na revista Piaui entre 2007 
e 2012. Em duas seções separadas, situadas no final, o livro traz trechos de diversas entrevistas e uma bibliografia. A bela apresentação que antecede tudo é assinada por Fabio Mascaro Querido e Ruy Braga. O que se pode dizer da "obra"? De um lado, que, a despeito da relevância de cada linha do que escreve Francisco de Oliveira, o material em questão não é inédito. De outro, porém, a republicação de seis textos importantes (com os acréscimos referidos) compensa. Talvez, o livro seja apenas um pretexto para homenagear a quem tem pensado o Brasil de forma original. Mas, Chico merece mais!

SILVEIRA, Rogério L. L. da; FELIPPI, Ângela C. T. Territórios, redes e desenvolvimento regional: perspectivas e desafios. Florianópolis: Ed. Insular, 2018.

Esta coletânea é um dos produtos de um evento que, a cada dois anos, vem agitando o campo do desenvolvimento regional no Brasil e na América Latina: o VIII Seminário Internacional sobre Desenvolvimento Regional, realizado em setembro de 2017 na cidade gaúcha de Santa Cruz do Sul, sob os auspícios do Programa de Pós-Graduação em Desenvolvimento Regional-UNISC. Em consonância com o tema mais geral do seminário - "Territórios, Redes e Desenvolvimento Regional: perspectivas e desafios" -, a coletânea reúne 11 contribuições de renomados especialistas brasileiros e estrangeiros. Se outro importante produto corresponde aos anais, que disponibiliza o conjunto de trabalhos apresentados em formato eletrônico, a publicação desta coletânea é muito bem-vinda por tornar acessível os textos que, afinal, animaram grande parte dos debates ocorridos naquele inesquecível evento.

SOUZA, Ricardo Luiz de. Pensamento social brasileiro: de Euclides da Cunha a Oswald de Andrade. São Paulo: Alameda, 2018.

Este livro, que não alcança bem 250 páginas, interessa, sobretudo, por dedicar-se a revisitar importantes estudiosos do Brasil que, temporalmente, antecedem a chamada "geração dos anos 1930”. Em seus sete capítulos, Ricardo Luiz de Souza passa, diligentemente, em revista oito (alguns dos quais, bem; outros, menos) conhecidos intérpretes que se debruçaram sobre problemas que dizem respeito, por exemplo, à cultura brasileira e à identidade nacional. Como informa o autor na introdução, o "objetivo é estudar alguns aspectos básicos e diretrizes do pensamento social brasileiro elaborado nas primeiras décadas do século XX a partir de um conjunto de autores fundamentais no processo de interpretação do Brasil delineado no período". Concluída a sua leitura, é possível visualizar um razoável quadro do que e de como se pensava o Brasil na virada do século XIX ao século XX. Não é pouco. 